\title{
The effect of environmental administrative penalty on firm's cash flow: evidence from China
}

\author{
Xiangan Ding ${ }^{1, *}$, Mohsin Shahzad ${ }^{2}$ \\ ${ }^{1}$ School of Government, Liaoning Normal University, Dalian, China \\ ${ }^{2}$ School of Economics and Management, Dalian University of Technology, Dalian, China
}

\begin{abstract}
Ecological deterioration and environmental damage brought by high-speed economic growth in China caused high attention. Environmental administrative penalty is a powerful way for the government to realize environmental pollution control. When a firm is subjected to environmental administrative penalties, how the penalty affects operating cash flows is an important issue of concern to academic and practical circles. This paper examined the relationship between the environmental administrative penalty and the firm's operating cash flow by using the ordinary least square method. It is found that environmental administrative penalty significantly decreases the firm's operating cash flow in the following year. To increase the robustness of the result, the potential endogenous problems have been eliminated by using the two-stage least squares method. We found that the negative effect still exists. The finding increases the understanding of how environmental administrative penalties affect the firm operation and have practical enlightenments to corporate environmental management and environmental pollution control.
\end{abstract}

\section{Introduction}

Severe ecological deterioration and environmental damage brought by high-speed economic growth in China caused high attention at home and abroad. How to effectively control environmental pollution has always been the focus of current policy discussions. Environmental administrative penalty will act as a deterrent to environmental pollution companies and play an important role in reducing environmental pollution. Therefore, the penalty is not only a means of environmental regulation but also a powerful way to realize pollution control. In 2014, National People's Congress Committee deliberated and adopted the Environmental Protection Law of the People's Republic of China, which was implemented on January 1, 2015. The revised Environmental Protection Law has strengthened the efforts of the government and environmental authorities to handle these kinds of environmental violations. Therefore, the number of cases investigated and dealt with by environmental protection departments under the new law has increased substantially. Official figures show the number of illegal cases filed and dealt with was 97000, 137800, 233000, 186000 , and 162800 respectively from 2015 to 2019 , with an average annual growth of more than 40 percent. The amount of environmental administrative penalties was 4.25 billion RMB, 6.63 billion RMB, 11.58 billion RMB, 15.28 billion RMB, and 11.878 billion RMB respectively from 2015 to 2019 , and the annual average growth rate is close to $50 \%$.
Cash flow is the income stream resulted from the firm's business activities [1]. Operating cash flows mainly include cash received for the sale of goods and services, return of taxes and fees received, and other operating-related cash received. Environmental administrative penalties don't just mean fines; it is more likely to harm both the capital chain of the company and the operation. So, how environmental administrative penalty affects a firm's operating cash flow, is an important issue of concern to practical circles.

Environmental penalties bring fines and force production to rectify, which may undermine or interrupt a firm's normal operation and business activities. Environmental violations also mean that the firm's environmental credit has been damaged, which may affect the firm's cash flow for some time [2]. On the one hand, a firm's access to the supply chain system may be hampered by penalties, and negative perceptions may generate in consumers' minds. Green consumers will be reluctant to buy goods and services from environmentally illegal companies, reducing sales revenue for penalized companies [2-6]. On the other hand, the tax breaks, subsidies, electricity and water concessions received by companies as a result of previous green production, as well as the government's preferential right to purchase, maybe negatively affected after being penalized. Taking value-added tax (VAT) as an example, the State Administration of Taxation of China has clear penalization measures for environmental pollution. If the firm's pollution discharge reaches the standard, the government will reduce the value-added tax of the company. Besides, companies penalized for

\footnotetext{
${ }^{*}$ Corresponding author: dingxa@qqq.com
} 
violating environmental laws and regulations are prohibited from applying for VAT relief for the next three years. Therefore, we suppose that environmental penalties may harm a firm's business activities.

In the existing literature, very less consideration has been given to how the environmental administrative penalty affects a firm's cash flow. Some researchers examined whether corporate financing was affected by punishment from securities regulators, corporate crime, corporate fraud, etc. [7-10]. For example, Johnson et al. (2014) found that corporate fraud negatively affected a firm's ability to source financing [11]. Gong et al. (2020) found that the effect of punishment announcements on debt financing was partially offset by prior CSR performance [8]. Song and Han (2017) found that corporate crime harmed the stock market and firms' cash flow [7]. Haß et al. (2019) suggested that fraud revelations increased a firm's information and credit risk, and therefore affected future loan conditions and cash flow [10]. However, previous studies focus on corporate financing and lack of attention to the effect of environmental penalties on expected operating cash flow. So, will environmental administrative penalties reduce the firm's operating cash flow? It is the focus of our study.

To solve such problems, we adopt 2SLS method and regression analysis to test the effect of the penalty on the cash flow. From the perspective of operating cash flows, our empirical results verify that environmental penalties negatively affect the cash flow in the flowing year. This study helps to identify the economic consequence of environmental administrative penalties from the perspective of corporate cash flow, which has strong practical enlightenment to the practice of corporate environmental management and government environmental regulation.

\section{Material and Methods}

\subsection{Sample and data}

The companies under investigation are all manufacturing companies listed on the Shanghai and Shenzhen stock exchanges in China. China's environmental conservation authorities have expanded their compliance activities in recent years. The Amendment of Environmental Protection Law, which increased the law enforcement authority of environmental protection agencies, was approved by the eighth meeting of the 12th National People's Congress in 2014. Since 2014, the number of environmental punishment cases increased significantly due to the government's focus on environmental conservation at the legislative level. As a result, we will now access more government details on listed firms' environmental violations. The Institute of Public and Environmental Affairs' database contains information on the environmental regulatory penalty. The CSMAR database provided us with financial details. After data collection, we got 316 listed companies.

\subsection{Variables and Measurement}

This study focuses on cash flows from operating activities, which are generated by all transactions and events other than the investment activities and financing activities of firms. Cash flow is usually measured by the value of operating cash flow minus capital expenditure. Here, capital expenditures include cash paid for the purchase of fixed assets, intangible assets, and other long-term assets, as well as the distribution of dividends and interest paid.

Environmental administrative penalties refer to the administrative sanctions imposed by the local government on the corporate that have committed environmental violations. The explanatory variable (PENALTY) represents the environmental penalty and is a dummy variable. If a company is subject to an environmental administrative penalty, the value is 1 ; otherwise, the value is 0 .

This paper refers to the relevant literature to select controlled variables [12-14]. Considering the impacts of enterprise size, financial standing, profitability, development ability, and other factors on the cash flow, we select asset size, asset-liability ratio, return on total assets, growth of operating income, environmental performance (GEP/PEP) and interest coverage ratio as controlled variables. Besides, environmental performance is also an essential factor [15-17]. Previous studies have mainly relied on CEP environmental performance ranking, TRI databases to measure environmental performance $[15,18]$. CEP and TRI contain data only on US corporations. To measure the EP of Chinese companies, Meng et al. (2014) designed a method similar to CEP to rank the environmental performance in three categories: poor, mixed, and good. This paper adopts the method. Hence, we set two dummy variables, namely GEP and PEP. Descriptions of variables are described in Table 1 below.

Table 1. Description of main variables

\begin{tabular}{|c|c|c|}
\hline Variables & Symbols & Descriptions \\
\hline Cash Flow & $\Delta \% C F$ & $\begin{array}{c}\text { Operating cash flow minus } \\
\text { capital expenditure }\end{array}$ \\
\hline $\begin{array}{l}\text { Environmental } \\
\text { administrative } \\
\text { penalty }\end{array}$ & PENALTY & $\begin{array}{l}\text { Dummy variable, if } \\
\text { penalized, value 1; } \\
\text { otherwise } 0 .\end{array}$ \\
\hline Firm size & SIZE & $\begin{array}{l}\text { Natural logarithm of the } \\
\text { total assets }\end{array}$ \\
\hline $\begin{array}{l}\text { Financial } \\
\text { leverage }\end{array}$ & $L E V$ & $\begin{array}{c}\text { Ratio of total liability to } \\
\text { total asset }\end{array}$ \\
\hline Financial Risk & INTCOV & $\begin{array}{l}\text { Ratio of annual pre-tax } \\
\text { profits to interest charges }\end{array}$ \\
\hline Profitability & $R O A$ & $\begin{array}{l}\text { Net profit/total assets at the } \\
\text { end of the year }\end{array}$ \\
\hline $\begin{array}{l}\text { Development } \\
\text { ability }\end{array}$ & GROW & $\begin{array}{l}\text { (Current operating profit - } \\
\text { last year operating profit)/ } \\
\text { last year operating profit }\end{array}$ \\
\hline \multirow{2}{*}{$\begin{array}{l}\text { Environmental } \\
\text { performance }\end{array}$} & GEP & $\begin{array}{l}\text { Dummy variable, if good } \\
\text { environmental performance, } \\
\text { value } 1 \text {; otherwise } 0 .\end{array}$ \\
\hline & $P E P$ & $\begin{array}{l}\text { Dummy variable, if poor } \\
\text { environmental performance, } \\
\text { value } 1 \text {; otherwise } 0 .\end{array}$ \\
\hline
\end{tabular}




\subsection{Econometric model}

To address our research question regarding the relationship between environmental administrative penalties and operating cash flow, we employ the following model:

$$
\begin{aligned}
& \Delta \% F_{\mathrm{i}, \mathrm{t}+1}=\alpha_{0}+\alpha_{1} \text { PENALTY } Y_{\mathrm{t}}+\alpha_{2} \text { SIZE }+\alpha_{3} \text { LEV } \\
& +\alpha_{4} \text { ROA }+\alpha_{5} \text { GROWTH }+\alpha_{6} \text { INTCOV }+\alpha_{7} \text { GEP } \\
& +\alpha_{8} \text { PEP }+\sum \text { INDUSTRY }+\sum \text { YEAR }+\varepsilon
\end{aligned}
$$

Here, referring to the studies of Dhaliwal et al. (2011) and Edwards et al. (2016), we take the change rate of cash flow as the explained variable. The design of using the change rate is more in line with the theoretical expectation, that is, the penalty causes the change of cash flow in the following year. Besides, it can effectively avoid metrological problems caused by the omission of relevant variables, and the endogenous problem of the model to a certain extent $[13,20]$. So, the use of first-order difference as a dependent variable is better than the use of the level of variable as a dependent variable.

\section{Empirical results and analysis}

\subsection{Descriptive statistics and correlation analysis}

The mean of the change rate in $C F(\triangle \% C F)$ is smaller than 0.001 , and the standard deviation is 0.42 . Overall, the average $C F$ varies a little in different years. But the standard deviation of variable value is relatively large, which reflects that the change rate of $C F$ of each company is quite different, and the reason is the critical problem to be discussed. Table 2 shows the Pearson correlation coefficient among the main variables. The correlation coefficient is less than 0.5 , and the VIF values are below 2 , indicating no multicollinearity among the main variables.

Table 2. Correlation coefficients between main variables

\begin{tabular}{|l|c|c|c|c|c|c|}
\hline Variables & $\Delta \% C F$ & $S I Z E$ & LEV & ROA & GROW & INTCOV \\
\hline$\Delta \% C F$ & 1 & & & & & \\
\hline$S I Z E$ & $0.13^{* *}$ & 1 & & & & \\
\hline$L E V$ & 0.01 & $0.20^{* *}$ & 1 & & & \\
\hline ROA & 0.03 & -0.01 & $-0.28^{* *}$ & 1 & & \\
\hline GROW & 0.02 & 0.03 & 0.02 & 0.03 & 1 & \\
\hline INTCOV & 0.00 & 0.03 & $-0.19^{* *}$ & $0.36^{* *}$ & -0.01 & 1 \\
\hline
\end{tabular}

Notes: $* \mathrm{p}<0.1, * * \mathrm{p}<0.05, * * * \mathrm{p}<0.01$.

\subsection{Regression results}

As is shown in Table 3, there was a significant negative correlation between the explanatory variable PENALTY $\left(\alpha_{1}=-2.08, \mathrm{p}<0.05\right)$ and explained variable $\Delta \% C F$. It means that environmental administrative penalties have a negative impact on cash flow in the following year.
Table 3. Effect of environmental administrative penalty on cash flow

\begin{tabular}{|l|c|}
\hline Variables & $\Delta \mathbf{\%} \mathbf{C F}_{\mathrm{i}, \mathrm{t+1}}$ \\
\hline Constant & $16.14^{* * *}(3.59)$ \\
\hline PENALTY & $-2.08^{* *}(-2.40)$ \\
\hline SIZE & $-0.92^{* * *}(-4.46)$ \\
\hline LEV & $7.91^{* * *}(5.98)$ \\
\hline ROA & $39.53^{* * *}(14.82)$ \\
\hline GROW & $0.06(0.68)$ \\
\hline INTCOV & $-0.02(-1.45)$ \\
\hline GEP & $-0.02^{* *}(-2.47)$ \\
\hline PEP & $0.02^{* *}(2.80)$ \\
\hline INDUS & Yes \\
\hline YEAR & Yes \\
\hline Adj-R & 0.22 \\
\hline F value & $16.21 * * *$ \\
\hline
\end{tabular}

Notes: ${ }^{*} \mathrm{p}<0.1,{ }^{* *} \mathrm{p}<0.05,{ }^{* * *} \mathrm{p}<0.01$.

The environmental administrative penalty can be classified as the pollution discharge exceeding the standard, the environmental pollution event, and construction projects against the environmental law. This study also examines whether various types of environmental administrative penalties harm the company's cash flow. The results show that the coefficients of PENALTY are significantly negative. It indicates that the negative relationship between environmental penalty and cash flow does not vary with the types of environmental penalty.

Many researchers considered that the relation between the occurrence of adverse events and corporate disclosure is not disturbed by endogenous problems(e.g. reverse causality, variable omitted, etc.) $[16,19,21]$. However, the decrease in cash flow may harm the company's environmental management activities, leading to insufficient cash for environmental protection, resulting in environmental violations. Perhaps the endogeneity exists in this study.

For solving possible reverse causality problems, this paper adopts two-stage least squares method (2SLS) to examine it. We selected the mean value of the total number of violation cases in the industry (Thy-num) as the instrumental variable. We got the mean value by dividing the total number of violations by the total number of companies in the industry. We hold that the greater the probability of violation in the industry, the more likely the company in the industry is to be penalized by environmental administrations. The probability of violations reflects the industry's compliance with environmental laws. Compliance with laws and regulations in the industry will directly affect whether the firm is subjected to environmental penalties. The mean value of the total number of violations in the industry can reflect the compliance with laws and regulations of similar companies in that year. Although the cash flow may vary between industries, we predict that the compliance with laws and regulations of the 
industry in that year will not directly affect the firm's cash flow.

In this paper, the two-stage least squares method (2SLS) is used to deal with the endogenous problem. We examined the impact of the penalty on CF $(\Delta \% C F)$. In Table 4, the Thy-num coefficient in the first stage regression is significantly negative, the same is expected in this paper. In the weak instruments test, the F value is significant at the level of $1 \%$. The original hypothesis of the weak instrumental variable is rejected, and there is reason to believe that the week instrumental variable does not exist. The coefficient of PENALTY in the second stage is -3.00 , which is significant at the level of $1 \%$. These coefficients are still consistent with the signs of the original coefficients, which prove the penalty reduces the cash flow in the following year.

Table 4. Effect of environmental administrative penalty on cash flow: test by 2SLS

\begin{tabular}{|l|c|c|}
\hline \multirow{2}{*}{ Variables } & (1) First-stage & (2) Second-stage \\
\cline { 2 - 3 } & PENALTY & $\Delta \% C F O_{i, t+1}$ \\
\hline Thy-num & $0.42^{* * *(3.98)}$ & $-3.00^{* * *}(-3.58)$ \\
\hline SIZE & $0.01(1.27)$ & $-0.84^{* * *}(-3.23)$ \\
\hline LEV & $-0.05(-0.90)$ & $7.12^{* * *}(3.77)$ \\
\hline ROA & $-0.10(-1.16)$ & $3.31^{* * *}(5.45)$ \\
\hline GROW & $-0.00(-0.24)$ & $0.06(0.73)$ \\
\hline INTCOV & $-0.00(0.62)$ & $-0.02(-0.10)$ \\
\hline GEP & - & $-0.03^{* *}(-2.60)$ \\
\hline PEP & - & $0.06^{* *}(2.61)$ \\
\hline Cons & $-0.21^{* * *}(-2.41)$ & $1.81^{* * *}(2.91)$ \\
\hline INDUS & Yes & Yes \\
\hline YEAR & Yes & Yes \\
\hline Adj-R ${ }^{2}$ & 0.04 & 0.20 \\
\hline F value & $2.81^{* * *}$ & $53.86^{* * *}$ \\
\hline $\begin{array}{l}\text { Weak } \\
\text { instruments test }\end{array}$ & - & - \\
\hline $\begin{array}{l}\text { Robust F- } \\
\text { statistic }\end{array}$ & $15.75^{* * *}$ & \\
\hline $\begin{array}{l}\text { F-statistic p- } \\
\text { value }\end{array}$ & 0.00 & \\
\hline
\end{tabular}

Notes: The values in parentheses in the list (1) of this table are $\mathrm{t}$ values; The values in parentheses in the list (2) are $\mathrm{z}$ values.

\section{Conclusion and discussion}

This study examines the impact of the environmental administrative penalty on cash flow. We found that there is a negative relationship between environmental administrative penalty and operating cash flow. The negative relationship between environmental penalty and cash flow does not change with the types of environmental penalty. After controlling endogenous problems, the negative effect still exists; this proves that the environmental administrative penalty significantly decreases the cash flow in the following year. We can infer that environmental administrative penalty harms operating activities, thus reducing the firm's operating cash flow.

To our knowledge, it is the first time to discover the relationship between environmental penalties and cash flow. Previous studies have discussed the impact of environmental violations on corporate reputation, capital costs, and less on the impact of environmental administrative penalties on corporate operations or cash flow. In this paper, we infer that the company's compliance with environmental regulations, environmental management helps the company to obtain stable operating cash flow. Besides, environmental administrative penalty damages the sustainability of the company's operation, so we suggest that the company should strengthen its environmental management so as not to adversely affect its operating cash flow due to environmental penalty. This finding provides new evidence from the perspective of environmental administrative penalties for economic consequences of environmental penalties and helps us to understand the significance of environmental management to firm sustainability.

From the perspective of government environmental governance, we have two enlightenments. First, environmental administrative penalty damages the normal operation of firms and causes firms to bear economic losses. This will force firms to protect the environment, control pollution emissions, so as not to be punished again. Second, environmental penalty can deter the firm's environmental illegal behaviour by damaging the firm's operating cash flow, which also shows that environmental administrative penalty can effectively control environmental pollution.

This study also has some limitations. In recent years, China's environmental protection authorities have strengthen environmental law enforcement. As such, we can obtain more data on environmental violations. Future studies should investigate longer-term data to assess the effect of environmental administrative penalties on operating cash flow. Besides, the environmental penalty not only affects cash flow but also may affect firm value. There is a lack of study on these problems in the literature, which needs further study.

\section{References}

[1] Gruca, T. S., \& Rego, L. L. Customer Satisfaction, Cash Flow, and Shareholder Value. Journal of Marketing, 69(3), 115. (2005)

[2] Albayrak, T., Aksoy, S.., \& Caber, M. The effect of environmental concern and scepticism on green purchase behaviour. Marketing Intelligence and Planning, 31(1), 27. (2013)

[3] Nguyen, T. N., Lobo, A., \& Nguyen, B. K. Young consumers' green purchase behaviour in an emerging market. Journal of Strategic Marketing, 26(7), 583. (2018)

[4] Joshi, Y., \& Rahman, Z. Predictors of young consumer's green purchase behaviour. 
Management of Environmental Quality: An International Journal, 27(4), 452. (2016)

[5] Kumar, P., \& Ghodeswar, B. M. Factors affecting consumers' green product purchase decisions. Marketing Intelligence and Planning, 33(3), 330. (2015)

[6] Mohr, L. A., \& Webb, D. J. The effects of corporate social responsibility and price on consumer responses. Journal of Consumer Affairs, 39(1), 121. (2005)

[7] Song, C., \& Han, S. H. Stock Market Reaction to Corporate Crime: Evidence from South Korea. Journal of Business Ethics, 143(2), 323. (2017)

[8] Gong, G., Huang, X., Wu, S., Tian, H., \& Li, W. Punishment by Securities Regulators, Corporate Social Responsibility and the Cost of Debt. Journal of Business Ethics, 1. (2020)

[9] Chen, Y., Zhu, S., \& Wang, Y. Corporate fraud and bank loans: Evidence from china. China Journal of Accounting Research, 4(3), 155. (2011)

[10] Haß, L. H., Vergauwe, S., \& Zhang, Z. Stateownership and bank loan contracting: evidence from corporate fraud. European Journal of Finance, 25(6), 550. (2019)

[11] Johnson, W. C., Xie, W., \& Yi, S. Corporate fraud and the value of reputations in the product market. Journal of Corporate Finance, 25, 16. (2014)

[12] Reverte, C. The Impact of Better Corporate Social Responsibility Disclosure on the Cost of Equity Capital. Corporate Social Responsibility and Environmental Management, 19(5), 253. (2012)

[13] Dhaliwal, D. S., Li, O. Z., Tsang, A., \& Yang, Y. G. Voluntary nonfinancial disclosure and the cost of equity capital: The initiation of corporate social responsibility reporting. The Accounting Review, 86(1), 59. (2011)

[14] Li, S., \& Liu, C. Quality of Corporate Social Responsibility Disclosure and Cost of Equity Capital: Lessons from China. Emerging Markets Finance and Trade, 54(11), 2472. (2018)

[15] Al-Tuwaijri, S. A., Christensen, T. E., \& Hughes, K. E. The relations among environmental disclosure, environmental performance, and economic performance: a simultaneous equations approach. Accounting, Organizations and Society, 29(5), 447. (2004)

[16] Clarkson, P. M., Fang, X., Li, Y., \& Richardson, G. The relevance of environmental disclosures: Are such disclosures incrementally informative? Journal of Accounting and Public Policy, 32(5), 410. (2013)

[17] Plumlee, M., Brown, D., Hayes, R. M., \& Marshall, R. S. Voluntary environmental disclosure quality and firm value: Further evidence. Journal of Accounting and Public Policy, 34(4), 336. (2015)

[18] Clarkson, P. M., Li, Y., Richardson, G. D., \& Vasvari, F. P. Revisiting the relation between environmental performance and environmental disclosure: An empirical analysis. Accounting, Organizations and Society, 33(4), 303. (2008)

[19] Meng, X. H., Zeng, S. X., Shi, J. J., Qi, G. Y., \& Zhang, Z. B. The relationship between corporate environmental performance and environmental disclosure: An empirical study in China. Journal of Environmental Management, 145, 357. (2014)

[20] Edwards, A., Schwab, C., \& Shevlin, T. Financial constraints and cash tax savings. Accounting Review, 91(3), 859. (2016)

[21] Ding, X., Qu, Y., \& Shahzad, M. The impact of environmental administrative penalties on the disclosure of environmental information. Sustainability, 11(20), 1. (2019) 